\title{
Student Teachers' Workplace-Based Learning in Sweden on Early Childhood Education for Sustainability: Experiences in Practice Settings
}

\author{
Eva Ärlemalm-Hagsér ${ }^{1}$ (D)
}

Published online: 15 September 2017

(C) The Author(s) 2017. This article is an open access publication

\begin{abstract}
Workplace-based learning experiences are integral to early childhood teacher education. In Sweden, the objectives of early childhood teacher education programmes require students to develop knowledge and skills about education for sustainability (EfS), in accordance with national policy documents. This includes how to work with EfS in everyday practice. The aim of this qualitative study was to critically analyse how pre-service teachers describe their workplace encounters with EfS, including dilemmas observed in practice and divergences in interpretation of EfS. The empirical data comprised 76 blogs (188 pages of text) written by preservice teachers as a requirement for a university course report about EfS in early childhood education. A document analysis was employed to critically examine the blogs through a reflexive interpretive process. The findings were revealing of both the students' meaning-making processes and their workplace supervisors' understandings of EfS. The findings depict different cultures of 'doing' EfS in early childhood settings, reflecting pluralistic and divergent landscapes of understandings as well as an absence of transformative whole-institution approaches in the implementation of EfS.
\end{abstract}

Keywords Critical theory · Education for sustainability · Early childhood education for sustainability · Higher education - Teacher education

Résumé Les expériences d'apprentissage en milieu de travail font partie intégrante de la formation des enseignants de la petite enfance. En Suède, les objectifs des programmes de formation des enseignants de la petite enfance obligent les étudiants à développer des connaissances et compétences en éducation au développement

Eva Ärlemalm-Hagsér

eva.arlemalm-hagser@mdh.se

1 School of Education, Culture and Communication, Mälardalens University, Box 883, Högskoleplan 1, 72123 Västerås, Sweden 
durable (EDD), conformément aux documents de la politique nationale. Cela comprend l'intégration de l'EDD dans la pratique quotidienne. L'objectif de cette étude qualitative est de faire une analyse critique de la manière dont les enseignants en formation initiale décrivent leur découverte de l'EDD sur le terrain, y compris les dilemmes observés dans la pratique et les interprétations divergentes de l'EDD. Les données empiriques comprennent 76 blogs (188 pages de texte) rédigés par des enseignants en formation initiale, comme rapport exigé dans le cadre d'un cours universitaire sur l'EDD en éducation de la petite enfance. Une analyse de documents a été utilisée pour faire l'examen critique de ces blogs à travers un processus réflexif d'interprétation. Les résultats sont révélateurs tant du processus de recherche de signification de l'EDD chez les étudiants que de la compréhension qu'en ont leurs maitres de stage. Les résultats illustrent différentes cultures de manière de «faire » de l'EDD dans les services d'éducation des jeunes enfants, reflétant la pluralité et la divergence des compréhensions ainsi qu'une absence d'approches transformatives globales des institutions dans la mise en œuvre de l'EDD.

Resumen Las experiencias de aprendizaje en entornos de trabajo reales son esenciales para la formación de los profesores de educación infantil. En Suecia, el objetivo de los programas de formación de profesores de educación infantil es el desarrollo de conocimientos y habilidades en cuanto a la Educación para el Desarrollo Sostenible (EDS) con arreglo a las normativas nacionales. Esto incluye cómo trabajar con la EDS diariamente. El objetivo de este estudio cualitativo es analizar de manera crítica cómo describen los profesores en formación su experiencia con la EDS durante su contacto con un entorno de trabajo real, e incluye los dilemas que han observado y las diferencias de interpretación de la EDS. Los datos empíricos utilizados fueron 76 blogs (188 páginas de texto) escritos por profesores en formación que la universidad les requería para elaborar después un informe sobre la EDS en el marco de la educación infantil. Se utilizó un análisis documental para examinar de manera crítica los blogs en un proceso interpretativo de reflexión. Los hallazgos nos han mostrado los procesos de generación de significado tanto de los profesores en formación como de sus supervisores en lo relativo a la comprensión de la EDS. Los resultados retratan las diferentes culturas de trabajo con la EDS en el ámbito de la educación infantil, reflejan paisajes de comprensión variados y divergentes y muestran una ausencia de enfoques transformadores en toda la institución en lo que concierne a la implementación de la EDS.

\section{Introduction}

Sustainability and education for sustainability (EfS) are not new concerns in higher education (HE), according to Wals and Blewitt (2010). There is a growing realisation that teacher education, in general, does not educate students about sustainability issues or prepare them to work in school contexts using frameworks on education for sustainability (Ferreira et al. 2009). EfS research in teacher education programmes is primarily concentrated on primary and secondary teacher education (Hopkins 2014) and, as yet, research focusing on early childhood 
education teacher education is not well recognised. This research addresses issues for students in teacher education on understanding EfS in practice. The research responds to the need for more studies in higher education on EfS and also responds to the marginalisation of research on EfS in early childhood teacher education (Davis 2015). This article analyses the experiences of early childhood student teachers in their encounters with EfS in their workplace-based learning experiences within their higher education course.

Early childhood teacher education in Sweden occurs at universities and university colleges. These programmes which are 3.5 years in length lead to a Bachelor's degree. According to the Swedish Higher Education Act (1992:1434, $5 \S$ ), these institutes have a specific responsibility to actively work to ensure that EfS permeates all activities. This education should enhance students' ability to develop a conscious approach to sustainability and to consider how democracy, justice, equity and distribution of power affect humans nationally, and globally, as well as to discuss and problematise human relations with the environment and nature. Furthermore, the students are expected to develop their pedagogical skills to implement EfS in practice.

The guiding questions informing this study were:

- How do early childhood student teachers describe EfS in encounters within their workplace-based experience?

- What dilemmas do the early childhood student teachers see in EfS in the context of early childhood education practices?

- Which critical aspects or divergences are visible in the interpretations of EfS in the early childhood education practices?

\section{Theoretical Underpinnings}

The theoretical underpinnings of this study derive from critical theory and ecofeminist perspectives (Fraser 2009; Moss 2010; Plumwood 2002). These perspectives acknowledge that current social reality is constructed and that political, moral and ethical values are embedded in the practices of institutions that are created within specific historical and cultural contexts (Dahlberg and Moss 2005). These perspectives recognise that value conflicts are inevitable when approaching sustainability issues (Hägglund and Johansson 2014).

In this article, the two concepts of 'education for sustainability' (EfS) and 'early childhood education for sustainability' (ECEfS) are aligned within a critical perspective that juxtaposes economic, social, ecological and political sustainability with issues of environmental sustainability, human equality and justice (Davis 2009; Fraser 2009; Plumwood 2002). It is also argued argue that sustainability education has developed towards a sense of place (nature- and ecology-oriented education) that should enhance the relationship between humans and non-humans, question hegemonic structures and values and engage multiple actors with conflicting views (Wals and Blaze Corcoran 2017). From this perspective, Fraser's (2009) concept of 
affirmative and transformative remedies is helpful. An affirmative approach can be described as actions that do not contest underlying structures of unsustainability and injustice, while a transformative approach focuses on deconstructing these underlying structures. From an ecofeminist perspective, Plumwood (2002) argues for a caring rationality that challenges the binaries between humans and nonhumans and nature and suggests this is one way to construct non-dominating interactions between humans and the natural world. In this caring rationality, important qualities are care, kindness and solidarity and these ideas underpin worldviews that are ethically aligned with sustainable futures.

Because higher education is the focus here, there is a need to clarify the role of sustainability education in higher education. According to Biesta (2011), the functions of education can be divided into three categories: qualifications, socialisation and subjectification. Firstly, education should contribute to students' qualifications, both with regard to their knowledge and skills, and as citizens. It should help them to advance and develop their questioning and critical attitudes. Secondly, educational institutions play a role in socialising students into society, passing on knowledge and values. Thirdly, education should invite students to be independent individuals. Aspelin (2015) has added a fourth category: 'existentialisation'. This focuses on the relational perspective of education-responding to others' responses and meaning-making.

Based on Biesta (2011) categories, I describe EfS in higher education as enabling students: (i) to develop knowledge and skills about sustainability, and their civic and leadership capabilities - and to be transformative intellectuals; (ii) to be socialised to develop their questioning and critical attitude towards unsustainable structures, actions and cultures, (iii) to develop relevant objectives according to their perspectives; and (iv) to discuss understandings and dilemmas from diverse perspectives and worldviews, amongst themselves, with their university teachers and workplace-based learning teachers. These assumptions support an approach based on participation, the creation of relationships for learning, and an ethic of empowerment, as proposed by Sterling et al. (2017).

\section{Education for Sustainability in Early Childhood Teacher Education}

EfS in early childhood teacher education is a marginalised area of research (Davis 2015; Ferreira et al. 2009). Teacher educators must learn to be agents of change with both content knowledge and leadership skills to support EfS in teacher education (Ferreira et al. 2014a, b, 2015). A model developed by Evans et al. (2016) illustrates how EfS was incorporated into the entire preschool teacher education programme in Queensland, Australia, from management level to instructional levels, and possibilities were created for institutional change. These authors also offered insights, strategies, examples and resources for others seeking to systematically implement EfS in higher education.

In the Swedish context, there is still a lack of studies about: (i) early childhood teacher education and (ii) early childhood education student teachers (Elliott et al. 2016; Ärlemalm-Hagsér and Sandberg 2011). This is despite the fact that EfS is 
stressed in both the Swedish Higher Education Act (1992:1434, 5§) and in the degree objectives (sustainable development) for the national early childhood teacher programme (Government Bill 2009/10:89).

In 2014, a pilot study for this research was conducted during the autumn university semester to study the extent to which the EfS learning outcomes were integrated into the Swedish early childhood teacher education programmes (Engdahl 2017). The survey was sent to all twenty universities and university colleges in Sweden that offered early childhood teacher programmes and 14 surveys were returned. Of these, 7 surveys showed examples of working with EfS and 7 surveys reported no compulsory or optional EfS course in their ECE teacher education programmes. Nonetheless, 10 participating institutions described EfS as having a relatively strong position within their programmes.

In an internal university evaluation, Ärlemalm-Hagsér (2015) analysed how EfS was integrated into the early childhood teacher education at Mälardalen University. The study demonstrated evidence of EfS in course offerings with varying levels of clarity. EfS was implemented in the programme stages to reflect the development of students' knowledge and skills. The stages were: (i) establishing knowledge about EfS as an objective (Semesters 1-2); (ii) consolidating and applying EfS in practice (Semesters 3-4); and finally, (iii) deepening the knowledge and critically examining multiple understandings and approaches-problematising ontological and epistemological perspectives on EfS in theory and practice (Semesters 5-7).

Even though EfS was incorporated into the programme at Mälardalen University, different interpretations and understandings emerged amongst staff about what the students should learn and what sustainability is 'or may be' in ECE settings, as there were no common definitions. This became obvious in the 19 course managers' responses. Several course managers argued that EfS could be clarified in relation to the specific aims and objectives of the course. Furthermore, some course managers raised the need to develop the structure, learning outcomes, goals and credits in their specific course for sustainability to become a clearer course objective. Another finding was that the progression of stages linked to EfS lacked a visible common thread linking the different stages and their objectives, and this needed to be more systematically embedded and developed.

\section{Method}

This article analyses how student teachers within ECE describe EfS in encounters within their workplace-based experience. A critical theory approach underpinned the research and a reflexive interpretive document analysis and abductive method of analysis was employed (Alvesson and Sköldberg 2009). This is a research process that oscillates between inductive and deductive analysis. The empirical data consist of 76 blogs (188 pages of text) written by ECE student teachers enrolled in a university EfS course held at Mälardalen University in 2015, 36 of whom were from the Eskilstuna campus (Student blog-Ex) and 40 from the Västerås campus (Student blog-Vx). The students were invited to describe in their blog their experiences of EfS in the early childhood setting in which they were completing workplace 
learning requirements of their teacher education course. Secondly, they were asked to reflect on sustainability issues while applying the Educational Rating Scale for Sustainable Development in Early Childhood (ERS-SDEC) (Kultti et al. 2016) with their course literature to support their problematising of ECEfS pedagogical practices. This rating scale was translated into Swedish in 2012 and has been tested several times (see Kultti et al. 2016). Thirdly, the students were encouraged to discuss their reflections and questions with their workplace-based teaching supervisor. Fourthly, the students posted their blogs on the university learning management system site.

Ethical issues were considered according to the guidelines of the Swedish Research Council (2011). The student teachers received information about the proposed research in a face-to-face lecture and by e-mail. They were informed about the aims, design and methods of the study, as well as about confidentiality and the handling and use of data. It was emphasised that their participation in the study was voluntary. They gave their informed consent to participate. A total of 76 out of 83 students took part in the study with their text (blogs). All material was handled with discretion and in accordance with the research-ethics requirement for protecting the integrity of participants.

\section{The Analysis Processes}

The analysis was carried out in four steps using a reflexive interpretive document analysis method, which invited critical reconstructions and re-representations of the data material (Alvesson and Sköldberg 2009; Denzin and Lincoln 2005).

In the first step, all the blog reports were read a number of times to obtain a sense of the whole body of data. This resulted in a general picture of the material, highlighting some overall features.

In the second step, the analysis was conducted with a focus on five dimensions: (i) the students' meaning-making and understanding of EfS objectives; (ii) dilemmas in ECEfS; (iii) critical aspects or disagreements visible in the interpretations of EfS; (iv) critical thinking for sustainability; and finally, (v) references to children as active participants in change. These dimensions build on other ECEfS research previously described.

In the third step, the following questions were explored within the data: Can these dimensions be found in all the blogs? What characterises blogs that do not exhibit the same dimensions? The purpose of this part of the analysis was to clarify hidden assumptions within the material (Alvesson and Sköldberg 2009).

In the final step, critical theory was utilised and consideration given to concepts of: affirmative and transformative strategies of change (Fraser 2009); children's participation and children as agents of change (Davis 2014); and caring rationality (Plumwood 2002). In addition, Biesta's (2011) and Aspelin's (2015) understandings of education were considered. This analytic approach was intended to expand the understandings of the social, economic, environmental and political dimensions of ECEfS and accentuate their interconnectedness. It also addresses epistemological, ontological and ethical issues about how to be a human or a non-human in a contradictory world, issues that teachers and children face every day. 


\section{Findings}

Three themes emerged from the blog data. These themes illustrate both the students' meaning-making and the workplace supervisors' understandings and responses. They also depict a specific set of cultures of 'doing' ECEfS. The three themes are: ECE student teachers' knowledge constructions about EfS; dilemmas in practising ECEfS; and finally, critical aspects and disagreements about ECEfS.

\section{ECE Student Teachers' Knowledge Constructions About EfS}

In the blogs, the ECE student teachers described a shift in their understandings of EfS, including that it is an ambiguous objective and that different understandings are held including how to connect the three dimensions. It was also noted how dialogues with supervisors were important to understanding ECEfS.

\section{Education for Sustainability-an Ambiguous Objective}

A majority of the ECE student teachers expressed in their blogs that their understandings of EfS had changed when they read the course literature and analysed the ERS-SDEC before visiting their workplace setting. Before the course started, the majority of the students had understood EfS as environmental and/or economic sustainability.

At the breakfast table, I'm thinking about the concept of 'sustainable development'. What does that really mean? It is such a big and comprehensive concept. Difficult to embrace and touch. Earlier, I only thought about it from an environmental perspective when I heard the concept. That it was about sorting trash, recycling, and so on... but the thing is, it's about so much more. After reading [the course literature], I now understand that sustainability can be seen from three dimensions: social and cultural sustainability, which is about justice, equality and survival; economic sustainability, which includes consumption and equitable distribution; and ecological/environmental sustainability, which addresses human impacts on the environment and ecology. (Student blog V24)

In the entries below, a broader understanding of EfS becomes visible in the students' descriptions. However, they still have many questions about how EfS is handled in their workplace settings.

I'm arriving at my workplace-based setting with many new thoughts and ideas about what EfS can mean. In the past, I have been rather unsure about the concept, and I felt that it was a bit abstruse and fuzzy. I've mainly looked at sustainability from an ecological and economic perspective, and I've associated it with sorting trash and recycling resources and materials, but it is much larger than that. We human beings have a shared responsibility to build a world that is stable in the long-term ecologically, economically and socially. However, how should it be taught in preschool? How should 
opportunities be created so that children can gain the skills they need to become/participate in a present-day/future society that is sustainable and stable? (Student blogV4)

The blog entries above show that the students have started to reflect about sustainability and EfS, as well as to problematise how they understood it before the course and how their understandings have changed. They also have begun to problematise how to work with EfS in practice.

\section{Connecting the Three Dimensions-Dialogues with Supervisors as Part of Understanding EfS in the ECES}

In the blogs, the students indicated an emerging awareness of the interconnections between the dimensions of sustainability, and a majority of the workplace supervisors supported their students in reflecting and asking questions about how the dimensions could be handled in practice.

Based on the conversation and the interesting discussions with my supervisor and the other educators, I can say two things. Firstly, that it is always possible to develop and improve work on sustainability; and secondly, that sustainability does not only mean working with issues related to our environment and surroundings, as I thought, but it also includes much more. (Student blog E22)

In the blog entry above, the student describes receiving support from a supervisor and other staff members when elaborating how EfS can be understood and practiced. In the next entry, the student and the supervisor co-construct knowledge about the social and cultural dimensions of sustainability.

When I [the student] arrived, they held a meeting that everyone in the team had to attend. After attending the team meeting for a short time, I noticed that they made a good deal of progress within one of the dimensions, social and cultural sustainability. They constantly strive to challenge stereotypical gender roles, and work continuously with people's equal value. After the meeting, we sat down, only me and my supervisor. I told her that they were working on sustainability when I joined the team meeting. She looked unbelievably puzzled and asked what I meant. I then took out the papers with the indicators and showed her what I meant about the social and cultural dimension of sustainability. Then she exclaimed, 'That's why I want students!' It felt incredibly good that she was so glad that I could come up with something that could contribute to their work. She told me that her idea of sustainability was composting and recycling. (Student blog E29)

The dialogues between the students and their supervisors often revealed a relationship where critical questions and reflections were welcomed and appreciated. Together they explored the practice and engaged in relational learning. 


\section{Dilemmas in Practising EfS in ECE}

The findings revealed several dilemmas, especially concerning what EfS means in practice and reflected the construction of different cultures of 'doing' EfS in the various settings. These dilemmas were how social and cultural sustainability was evident in monocultural versus multicultural settings, and how children's ages were relevant to EfS practices and the dependence on personal engagement with EfS for daily implementation.

\section{Monocultural Setting Versus Multicultural Setting}

The findings showed that different cultures of 'doing' EfS were constructed in the various settings. In the students' blogs, it was often discussed how best to work with EfS in multicultural settings, especially with regard to social and cultural sustainability. In some of the settings with a majority ethnicity (Swedish) amongst the children (monocultural settings), the teacher did not recognise any need to work with cultural diversity as part of the social and cultural sustainability.

I asked the staff if they talked a lot about diversity and different cultures. They said that they talk a lot about people's equal value, that we are all different and that it is okay. In the child group, there is a single child who 'looks different', but none of the children in the unit has both parents from another country. So, that's the reason that they do not talk so much about cultural diversity. (Student blog V27)

As seen in the entry, the ECE staff characterised multiculturality as having children who 'look different'.

As for the cultural part, I don't have so much to write about, because they don't work with it at all. The unit has no multiculturalism at all, and my supervisor said that it isn't a natural issue in the setting. (Student blog E11)

On the other hand, in the settings with a large group of children with minority ethnicity (multicultural settings) the teacher saw diversity engagement as important and necessary.

I follow the children into the unit; It feels like I'm constantly noticing different artefacts that could be one of those sustainability indicators that I read about. There are books in different languages from different cultures. Quite obviously anyway. My field ECES is a so-called multicultural setting. In addition to books, there are words in different languages on walls, floors and cabinets. In the home there are dolls that all come from different parts of the world. It is part of the official activities. We learn about and embrace each other's differences, but are united in our similarities. (Student blog V17)

According to the students' blogs, the nature of the work with social and cultural sustainability, especially diversity, depended on whether the settings were monocultural or multicultural. In some of the monocultural settings, the teacher did not consider the work with cultural diversity to be important. In others, they saw 
diversity as enriching the setting (as also seen in a blog entry under the heading Possibilities to understand EfS in a broader sense). In all settings described as multicultural, the work with diversity was seen as crucial by the teachers.

\section{Age as an Obstacle for Working with EfS}

In some of the settings working with the youngest children, age was an obstacle. It became clear that how children's competence was viewed by the teachers, in connection to age, regulated the settings' work with EfS in practice.

[...] the staff felt that the children were not of appropriate age. The children at the unit are just over 3 years old, and the staff said that conversations about sustainability might be better in the pre-school class or at school. (Student blog V36)

The teacher finds it difficult to see how we can encourage and support children in the preschool to critically review and question consumption and lifestyle patterns, as the indicators suggest. I think that the average 4-year-old critically reviews and questions most of what he or she sees and experiences. (Student blog V9)

In other settings, age was not an obstacle at all; they worked with EfS, organising activities across the three dimensions of sustainability.

During the interview, the teacher reported that in a unit for the youngest children [aged 1-3], the educators need to be observant, pay attention to the children's discoveries and name everything; this is essential for children's development and learning. She explains that all the work teams must be good role models in how they relate to animals, nature, the environment and people. (Student blog V4)

In some of the settings, children's age is an obstacle to EfS; in others the staff work with all aspects of sustainability even with the youngest children, aged $1-3$ years.

\section{Dependence on Personal Engagement with EfS for Daily Implementation}

In the blogs, the students often mentioned the teachers' personal engagement with EfS issues. This personal engagement was often related to the teachers' involvement with environmental and nature issues. Also, a lack of interest amongst other staff members in working with EfS in the setting becomes visible for the students.

I noticed that there was a lack of commitment among some of the educators, which meant that there was only one [staff member] in the unit who worked with sustainability in the best way. This means that if the dedicated staff member not is at work, it does not get done in the same way when the other educators do it. (Student blog E4) 
The teachers' level of commitment seems to be crucial in ECEfS. In several blogs, the students described that the teachers in the settings were committed to sustainability issues and that this personal commitment influenced their work. They also described the dilemmas that arose when only one person was committed to working with EfS, and when that person is not in place, nothing related to EfS happens.

\section{Critical Aspects of EfS and Disagreements About it in the ECES}

Critical aspects or disagreements were visible in the blogs. The findings exemplified how EfS was interpreted and understood by the supervisors, how children's participation in the practices was viewed, and the absence of a transformative approach by the whole institution.

\section{Disagreements About the Interpretation of EfS in Practice}

In some of the blogs, the students described that there was a disagreement between them and their supervisors about the practices and the dimensions and objectives that were part of ECEfS.

When I raised the issue of economic sustainability, my supervisor said that it was not part of sustainable development, so I had to explain to her why it does belong to it. It also seemed like she got a bit angry when we discussed it, because she constantly said that the children were too young to take financial responsibility, which I agree with, but that's not what economic sustainability is about. My supervisor mentioned that the preschool works more with social and cultural sustainability, because educators consider this the most important dimension to work with. (Student blog E2)

One student expressed that he/she felt resistance from the supervisor to discussing EfS and how it was handled in the setting.

On my way back home, thoughts about the ECES work on sustainability came to mind. In my conversation with my supervisor, I could sense some resistance. As I interpret what we talked about, I think that sustainability is a set of values and a way of life to a much greater extent than what the supervisor wants to admit or can relate to. I really like this preschool, their way of working in relation to the assignment and the cohesion that permeates the setting, but my opinion, then as now, is that they have a long way to go in their work for sustainability. (Student blog V9)

A handful of students described tensions and resistance in their discussions with their supervisors. The texts in the blogs indicated that the students who experienced this felt that it was problematic for them. Nevertheless, students described discussing this with their supervisors and arguing for their understandings of EfS, and even give expression to this in their blogs. 


\section{Children as Agents of Change—or as Taking Part in Different Activities}

In a majority of the blogs, the students described that the teachers talked with the children about different sustainability topics. Some of the students reacted to how the teachers talked—not with the children, but to them.

What I missed in the preschool's work with sustainability is a view of the children as actors; and, it is primarily the adults' attitudes that are preached to the children, instead of the children themselves being able to come up with thoughts and ideas. However, in the social dimension, I can see that the children are involved in an activity that is democratic and characterised by solidarity, where the children's thoughts and solutions are highly valued, but here too, it is often primarily the teachers' attitudes that are being taught and focused upon. Had I spent more time observing the activities at the preschool, I would have gained insight into how involved the children are in the work with sustainability. It is difficult to get a correct picture of the activity solely on the basis of brief observations, and furthermore it is not certain that the supervisors' picture of reality is in line with that of others. (Student blog E36)

Another example of the same issue concerned what objectives the teachers should teach children in ECEfS.

Sustainability! Something that is really a hot topic now. People are working with sustainability in various forms, both here and there. The question is whether the children, our future world citizens, will learn what it means and how to make the world a sustainable place to live. With war, rainforest devastation, the extreme right, countries experiencing inflation, and more and more people who lack food or a place to live, it is perhaps not so strange that issues of sustainability are being addressed more and more. We only have one world to share, and we need to take care it, if we are to be able to live here for more generations. This is perhaps where ECE sometimes falls short, when it comes to knowing why it is so important to work for sustainability. Perhaps it's mostly done as pure routine, or as something that 'has to' be done. The children are our future and it is they who need to make a difference when they grow up. It is our job in the preschools to create the foundations of their commitment, and sustainability is an important thing to create commitment about in the children. In my workplace setting, they mostly work with the part that deals with ecology and the environment. Of course, one thinks to teach the children about, for example, everyone's equal value, but that is in the curriculum, so it has to be done. Solidarity with our fellow human beings on the other side of the world is probably not as high a priority. (Student blog V8)

The students raised questions in their blogs about children's participation and the lack of seeing children as agents of change. Another perspective expressed in the blogs concerned what objectives and activities children have the opportunity to encounter in their settings. 


\section{Absence of a Transformative Whole-Institution Approach}

A pattern in the blogs was the absence of a transformative whole-institution approach. Several of the student teachers expressed in their blogs that they were disappointed after their visit to their workplace-based setting.

I felt very disappointed after my visit to the field setting. When I went, I thought that I would gather a huge amount [of information], because they [in the field setting] are always talking about what great work they do with sustainability, but unfortunately my expectations were not met. Instead I was rather shocked to find that the work is as flawed as it actually is. In my opinion, you have failed as an educator if you cannot make use of the children's curiosity and create inspiring activities. Are they [kids] ever too young to get to do fun things? I don't think so, at least. (Student blog V15)

The workplace settings described in the student blogs were rarely working with EfS in a systematic way that embedded sustainability in the everyday activities and routines. There were only a few settings that had a clear vision about EfS and worked with all dimensions in a holistic manner. Several of the students were disappointed about what they found, as before starting this workplace study, they had assessed their workplace as a high-quality setting.

A number of critical aspects and disagreements became visible in the blogs. There were disagreements between students and supervisors about the interpretation of sustainability and its dimensions, objectives and activities. Another aspect was that, according to the students' blogs, participation and agency amongst the children were lacking, and instead of having possibilities to be agents of change, the children took part in different activities that the teachers planned by themselves. An additional critical aspect was the absence of a transformative whole-institution approach in the settings. On the other hand, all the workplace settings worked with EfS in different ways. In 34 of the blogs, the students wrote that their workplace setting was certified by Green Flag. The efforts to reduce consumption and reuse and recycle materials were as integral to everyday life, as were outdoor play and learning about nature. Social and cultural issues such as equality and fairness were objects of mostly genuine commitment in the settings, but not seen as 'doing' sustainability. Hence, the three sustainability dimensions were not viewed from a holistic perspective; instead they were seen as a collection of separate parts.

\section{Discussion}

In this article, I have analysed how early childhood student teachers described EfS encounters within their workplace-based experience. This study responds directly to the lack of research in higher education and EfS research (Ferreira et al 2014a, b), especially the marginalisation of research on EfS in early childhood teacher education (Davis 2015). In response to the research questions, the discussion considers: early childhood student teachers' encounters within their workplacebased experience; dilemmas with EfS seen by student teachers in the ECES; critical 
aspects or divergences visible in the interpretations of EfS in the ECE practices; and links to earlier studies.

An important part of Swedish ECE teacher education is the students' workplacebased experiences and the support they receive from their supervisor and other staff in the workplace setting. The setting is allocated to them by the university administrative division and university workplace coordinators; therefore, the students cannot decide for themselves their workplace. In the student teachers' descriptions of their workplace-based encounters, a pluralistic and divergent landscape of EfS understandings became visible. This illuminated the different ways that students understood EfS, before and after their workplace-based experiences, the different ways that the supervisors and other staff members interpreted EfS, the various sustainability dimensions, and how it was evident in practice. It also illustrated that there were different understandings about children and childhood amongst the staff members. Understandings that construct diverse cultures in the settings.

Following Biesta's (2011) three categories of the functions of education, 'qualifications', 'socialisation' and 'subjectification', and Aspelin's (2015) fourth category, 'existentialisation', EfS in higher education is understood here as enabling students: (i) to develop knowledge and skills about sustainability, and their civic and leadership capabilities - and to be transformative intellectuals; (ii) to be socialised to develop their questioning and critical attitude towards unsustainable structures, actions and cultures; (iii) to develop relevant objectives according to their perspectives; and (iv) to discuss understandings and dilemmas from a broad spectrum of different viewpoints and worldviews, amongst themselves, with their university teachers and with their workplace-based learning supervisors.

(i) The student teachers developed knowledge and skills about sustainability, as well about how to pedagogically implement, contingent upon their workplace experiences and prior knowledge. What was not obvious in the blogs was whether the majority of the students deepened their understanding of civic and leadership capabilities and how to be transformative intellectuals.

(ii) The dialogues between the students and their supervisors often showed coconstructive relationships, where critical questions and reflections were welcomed and appreciated. Together they explored practices and learned from each other about EfS and the ERS-SDEC. This can be interpreted the students being socialised into the culture of ECE, and developing their questioning and critical attitudes towards unsustainable structures, actions and cultures together with their supervisors.

(iii) In some blogs, the students described disagreements with their supervisors about interpretations of sustainability and its dimensions, objectives and activities. Often these dilemmas, critical aspects and disagreements were seen from the students' point of view as relevant objectives, and the students were disappointed that the setting did not meet their expectations of a high-quality setting with regard to EfS. 
(iv) Possibilities to discuss understandings and dilemmas from a broad spectrum of different viewpoints and worldviews, amongst themselves, with their university teachers and with their workplace-based learning supervisors were evident. Several student teachers raised questions about the emergence of different working cultures and supervisors' and staff members' differing constructions and ideas about what children should experience and learn. The blogs gave examples of how ethnicity and age influenced EfS in practice, and what objectives and activities were linked ECEfS in the settings. Another example in the blogs was that children's participation and agency were deficient - that instead of having possibilities to be agents for change, the children participated in different activities that the teachers alone planned. According to Davis (2014), one of the most important aspects of working with ECEfS is promoting children's participation and agency. Children should have the right to vice opinions in matters that affect them and to participate as social agents in practice and in research (Barratt-Hacking et al. 2013; Davis 2014; UNCRC 1989).

Beyond these categories, I note a transformative whole-institution approach was absent in the settings and all the workplaces implemented EfS in different ways integral to their contexts. As previously discussed, a large group of the settings were certified by Green Flag (see, for example, Ärlemalm-Hagsér and Sundberg 2016). The settings economic sustainability was achieved by reducing consumption and reusing and recycling materials in everyday activities. They also worked with ecological sustainability by learning about nature indoors and outdoors. There was also a genuine commitment to social and cultural issues such as equality, equity and fairness evident. This implied that the work with EfS was seen as consisting of a number of separate parts, not holistically (see, for example, Hedefalk et al. 2015; Kultti et al. 2016). Employing Fraser's (2009) terminology, this can be analysed as an affirmative practice that does not challenge underlying structures and systems of hegemonic certainties and understandings.

\section{Conclusion and Implications}

These findings have implications for ECE practice and teacher education, as well as for further research. There is a significant need for further studies as to how teacher education can promote students' critical thinking in general, and about sustainability questions in particular; how students can develop knowledge and skills to be transformative intellectuals and leaders of change; and further, how capacities for action with empowerment can be actualised. These are the abilities and skills also needed by staff in ECE settings.

Another perspective to be further addressed concerns the epistemological, ontological and ethical issues of interconnectedness, care and how to be a human or a non-human in a contradictory world, issues that teachers and children face daily (Davis and Elliott 2014; Green 2015; Plumwood 2002; Somerville and Williams 2015) There is an urgent need to generate counter-hegemonic ways of seeing and 
understanding the world to secure global change for sustainability. This study illuminates meanings that are tacitly built into the system of organised everyday life in the institution (HE and ECE) - a hidden curriculum, where subjectivities are produced and regulated. These institutions must be active political sites for acknowledging and addressing the tensions and possibilities for sustainability.

This article concludes with a quotation from one of the student teachers that encapsulates her workplace-based setting's work on sustainability: 'Beautiful on the surface but empty inside'. (Student blog V12)

Open Access This article is distributed under the terms of the Creative Commons Attribution 4.0 International License (http://creativecommons.org/licenses/by/4.0/), which permits unrestricted use, distribution, and reproduction in any medium, provided you give appropriate credit to the original author(s) and the source, provide a link to the Creative Commons license, and indicate if changes were made.

\section{References}

Alvesson, M., \& Sköldberg, K. (2009). Reflexive methodology. New vistas for qualitative research. Los Angeles: SAGE.

Ärlemalm-Hagsér, E. (2015). Report on mainstreaming education for sustainable development in the preschool teacher program. Västerås: Mälardalens University.

Ärlemalm-Hagsér, E., \& Sandberg, A. (2011). Sustainable development in early childhood education: inservice students' comprehension of the concept. Environmental Education Research Journal, 17(2), $187-200$.

Ärlemalm-Hagsér, E., \& Sundberg, B. (2016). Nature experiences and recycling-A quantitative study on education for sustainable development in Swedish preschools. Nordina, 12(2), 140-156.

Aspelin, J. (2015). The elementary forms of educational life: Understanding the meaning of education from the concept of "social responsivity". Social Psychology of Education, 18(3), 487-501.

Barratt-Hacking, E., Cutter-Mackenzie, A., \& Barratt, R. (2013). Children as active researchers: The potential of environmental education research involving children. In R. B. Stevenson, M. Brody, J. Dillon, \& A. Wals (Eds.), International handbook of research on environmental education (pp. 438-458). New York: Routledge.

Biesta, G. (2011). Learning democracy in school and society. Education, l Life long learning and the politics of citizenship. Rotterdam: Sense Publishers.

Dahlberg, G., \& Moss, P. (2005). Ethics and politics in early childhood education. New York: Routledge Falmer.

Davis, J. (2009). Revealing the research 'hole' of early childhood education for sustainability: A preliminary survey of literature. Environmental Education Research, 15(2), 227-241.

Davis, J. (2014). Examining early childhood education through the lens of education for sustainability: Revisioning rights. In J. Davis \& S. Elliott (Eds.), Research in early childhood education for sustainability: International perspectives and provocations (pp. 21-37). New York: Routledge.

Davis, J. (Ed.). (2015). Young children and the environment: Early education for sustainability (2nd ed.). Cambridge: Cambridge University Press.

Davis, J., \& Elliott, S. (Eds.). (2014). Research in early childhood education for sustainability: International perspectives and provocations. London: Routledge.

Denzin, N. K., \& Lincoln, Y. S. (2005). The Sage handbook of qualitative research (3rd ed.). London: Sage.

Elliott, S., Carr, V., Ärlemalm-Hagsér, E., \& Park, E. (2016). Examining curriculum policy and pedagogy across borders: Re-imagining socially transformative learning in early childhood education. In P. Blaze Corcoran, J. Weakland, \& A. Wals (Eds.), Envisioning futures for environmental and sustainability education (pp. 205-216). Wageningen: Wageningen Academic Publishers.

Engdahl, I. (2017). Education for sustainability in Swedish preschool teacher education: A survey. Stockholm: OMEP. 
Evans, N., Ferreira, J., Davis, J., \& Stevenson, R. (2016). Embedding EfS in teacher education though a multi-level system approach: Lessons from Queensland. Australian Journal of Environmental Education, 32(1), 65-79.

Ferreira, J., Ryan, E., \& Davis, J. (2015). Developing knowledge and leadership in pre-service teacher education systems. Australian Journal of Environmental Education, 31(2), 194-207.

Ferreira, J., Ryan, E., Davis, J., Cavanagh, M., \& Thomas, J. (2009). Mainstreaming sustainability into pre-service teacher education in Australia. Canberra: Australian Research Institute in Education for Sustainability, Australian Government Department of Environment, Water, Heritage and the Arts.

Ferreira, J., Ryan, L., \& Tilbury, D. (2014a). Planning for success: Factors influencing change in teacher education. Australian Journal of Environmental Education, 30(1), 136-146.

Ferreira, J., Ryan, L., \& Tilbury, D. (2014b). A response to reorienting teacher education towards sustainability. Australian Journal of Environmental Education, 30(1), 147-148.

Fraser, N. (2009). Scales of justice: Reimagining political space in a globalizing world. New York: Columbia University Press.

Government Bill (2009/10:89). Top of the class-new teacher education programmes. Stockholm, Swedish Parliament.

Green, C. (2015). Toward young children as active researchers: A critical review of the methodologies and methods in early childhood environmental education'. Journal of Environmental Education, 46(4), 207-229.

Hägglund, S., \& Johansson, E. M. (2014). Belonging, value conflicts and children's rights in learning for sustainability in early childhood. In J. Davis \& S. Elliott (Eds.), Research in early childhood for sustainability: International perspectives and provocations (pp. 38-48). London: Routledge.

Hedefalk, M., Almqvist, J., \& Östman, L. (2015). Education for sustainable development in early childhood education: A review of the research literature. Environmental Education Research, 21(7), 975-990.

Hopkins, C. (2014). Scope and impact of global actions under UNDESD. Journal of Education for Sustainable Development, 8(2), 113-119.

Kultti, A., Larsson, J., Ärlemalm-Hagsér, E., \& Pramling Samuelsson, I. (2016). Education for sustainability in the context of Swedish preschool. In I. J. Siraj-Blatchford, E. Park \& C. Mogharreban (Eds.), International research on education for sustainable development in early childhood (pp. 123-137). Dortreched, Springer Books.

Moss, P. (2010). We cannot continue as we are: The educator in an education for survival. Contemporary Issues in Early Childhood, 11(1), 8-19.

Plumwood, V. (2002). Environmental culture: The ecological crisis of reason. New York: Routledge.

Somerville, M., \& Williams, C. (2015). Sustainability education in early childhood: An updated review of research in the field. Contemporary Issues in Early Childhood, 16(2), 102-117.

Sterling, S., Glasser, H., Rieckmann, M., \& Warwick, P. (2017). "More than scaling up": A critical and practical inquiry into operationalizing sustainability competences. In P. B. Corcoran, J. Weakland, \& A. Wals (Eds.), Envisioning Futures for Environmental and Sustainability Education (pp. 153-168). Wageningen Academic Publishers: Wageningen.

Swedish Higher Education Act. (1992:1434). Stockholm, Ministry of education and research.

Swedish Research Council. (2011). Good research practice. Stockholm: Swedish Research Council.

UNCRC. (1989). The UN convention on the rights of the child. New York: United Nations.

Wals, A., \& Blewitt, J. (2010). Third wave sustainability in higher education: Some (inter)national trends and developments. In P. Jones, D. Selby, \& S. Sterling (Eds.), Green infusions: Embedding sustainability across the higher education curriculum (pp. 55-74). London: Earthscan.

Wals, A., Weakland, J., \& Blaze Corcoran, P. (2017). Introduction. In P. B. Corcoran, J. Weakland, \& A. Wals (Eds.), Envisioning futures for environmental and sustainability education (pp. 19-29). Wageningen Academic Publishers: Wageningen. 